\title{
Transnational Professional Competition in Fields and Ecologies
}

\author{
Rasmus Corlin Christensen, Copenhagen Business School, rcc.dbp@cbs.dk
}

DRAFT VERSION, JULY 2017. ALL COMMENTS WELCOME.

\begin{abstract}
Transnationalisation of economies, organisations and societies have fundamentally reconfigured professional life. Dispersal of authority and activity away from national confines has spawned new transnational modes of organisation and competition amongst professionals. Studies of transnational professional competition explore how professionals broker normative, institutional and political change through these struggles in spaces 'beyond the state'. This paper reviews existing work on transnational professional competition, focusing on two dominant streams: studies associated with Pierre Bourdieu's field theory and studies associated with Andrew Abbott's ecological theory. It discusses the key theoretical dynamics and empirical focus of each stream. Furthermore, the paper reviews the ongoing debate between the two streams, drawing out proposals for mutual learning at the intersection of field and ecology studies. It is argued that such a closer exchange has potential to address points of contention and exploit points of convergence, enhancing understanding of specifically transnational professional relations, institutional change, social contexts and social structures.
\end{abstract}

Keywords: Transnational, Professionals, Elites, Field, Ecology, Power, Competition. 


\section{Introduction}

Whereas historically, the nation-state provided the main spatial locale for professional activity, the past decades have witnessed rapid integration of global economies, organisations and societies. In consequence, professional life, its institutional environment and its socio-economic impacts have become increasingly transnational in nature (Haas 1992; Hannerz 1996; Djelic and Quack 2010). This has led to scholarly attention to the transnational dimensions of professional action, in particular competition and conflict amongst professionals for various benefits (Faulconbridge and Muzio 2012; Seabrooke 2014). As professionals have moved beyond entrenched national institutions and domestic politics, they have taken up central positions in contested transnational spaces, becoming involved in struggles around monopolies over professional tasks, institutional change and influence on global governance (Fourcade 2006; Suddaby, Cooper, and Greenwood 2007; Kauppi and Madsen 2013; Seabrooke and Henriksen 2017).

Studies of professional competition and its transnationalism have contributed important insights on the nature, origins and impacts of these socio-economic struggles, but the scholarship remains fragmented. It covers a range of empirical cases from various disciplines, and so far there has been little interaction amongst different schools of thought. Although distinct theoretical lenses and assumptions will and should remain, an examination of the prospects for synthesis can help conceptualise common ideas and outline potentials for learning. More importantly, such an exchange has potential to enhance understanding of specifically transnational professional dynamics, such as inter- and intra-professional relations, institutional change, social contexts and social structures. It can also help to address points of contention and exploit points of convergence.

This paper reviews existing studies on transnational professional competition and draws out proposals for mutual learning. It focuses on two dominant streams: studies associated with Pierre Bourdieu's field theory, emphasising dynamics of subordination and power dominance, and studies associated with Andrew Abbott's ecological theory, which embrace a more symbiotic dynamic of jurisdictional contestation. While there are notable incompatibilities across the two approaches to the study of transnational professional competition and theories upon which they build, there is equally significant common ground (Liu and Emirbayer 2016). The paper evaluates the core theoretical dynamics and empirical contributions of each stream, and discusses key points of contention as well as the prospects for convergence. Furthermore, it assesses the ongoing debate between the two streams, drawing out proposals for mutual learning at the intersection of field and ecology studies. In particular, the paper highlights potential in a broadened conceptualisation of social dynamics, the 
layering of field and ecology concepts, an emphasis on the wider socio-political-cultural context of transnational professional action, and methodological cross-fertilization. These arguments build on recent discussions of fields and ecologies more generally (Liu 2015; Liu and Emirbayer 2016) and of transnationalisation of professional field and ecology concepts (Fourcade 2006; Seabrooke and Tsingou 2009b; Vauchez 2011; Go and Krause 2016b)

The paper is structured as follows. The introduction is followed by a discussion of professionals in transnational spaces in Section 2. Section 3 identifies field and ecology approaches as central in scholarship on transnational professional competition, elaborating the two theoretical perspectives, including their differing core social dynamics and empirical application. Section 4 assesses points of contention and the prospects for convergence of the two streams. It highlights the clashing social dynamics, embeddedness of transnational actors, and methods, but also the convergence potential in terms of scientific philosophy, space diversity and origins of change. Section 5 draws out proposals for mutual learning from recent discussions within the field and ecology literatures. Finally, the conclusion sum up and reflects on the prospects for transnational professional competition scholarship.

\section{Professionals in transnational spaces}

Professionals have always played an important role in society, but that role has fundamentally changed over the past decades. Early theorists emphasised the role of professionals in ensuring the smooth functioning of society (Durkheim 1957, 1997), their contribution to social stratification (Weber 1968) and role in class dominance (Ehrenreich and Ehrenreich 1979) - but all conceptualised professionals as primarily national actors. Only fairly recently, with transnational socio-economic changes, have professionals come to been seen as transnational actors in their own right. Transnationalisation has fundamentally reconfigured professional life, spawning new transnational modes of organisation and action (Faulconbridge and Muzio 2012). As the issues professionals deal with have become detached from the national level, transnational communities have emerged that organise professionals around common ideas and projects rather than nationality (Haas 1992; Djelic and Quack 2010).

At its core, transnationality simply denotes phenomena that are "not contained within the

state" (Hannerz 1996, 6). More specifically, we can outline three key characteristics of transnationalism as it relates to professionals. First, transnational spaces are relatively more transient. Transnational spaces that are relatively more ephemeral, in flux, indeterminate and ontologically open 
(Buchholz 2016, 39). They are 'thinner' than national spaces, in the sense that they are less marked by long-standing, fixed orders. Thus, there is more autonomy, allowing professionals to assert authority, and for new constellations of professional institutions and norms to emerge. Consequently, there is also a greater openness of competition in transnational spaces, where professionals have taken up central positions in new transnational struggles, capitalising on the more fluid nature of these spaces (Seabrooke 2014). Second, this fluidity is closely related to the new and less fixed role played by nation-states in transnational spaces. The complexity of modern governance issues, across social spheres, has required states to delegate and diffuse authority to non-state actors, in turn reconfiguration its own role in transnational affairs. Authority has shifted, diffusing away from nation-states towards professional actors (Keck and Sikkink 1998; Hall and Biersteker 2002; Pattberg 2005; Djelic and Sahlin-Andersson 2006; Djelic and Quack 2010).

Third, this reconfiguration of authority sites has been accompanied by a reconfiguration of authority types. Rather than dominated by strict logics of command, transnational governance is characterised by alternative, 'softer' logics, such as delegation, orchestration, issue control and standard-setting (Mattli and Büthe 2003; K. W. Abbott and Snidal 2009; Faulconbridge and Muzio 2012; Seabrooke and Henriksen 2017). Professionals are uniquely positioned to part-take and capitalise on these transnational characteristics, as they are able to mobilise flexible sources of authority to struggles organised "beyond the state" (Seabrooke 2014; Kauppi and Madsen 2014).

The literature on transnational professional competition has explored how professionals broker normative, institutional and political change in these transnational spaces. These studies pay attention to the competition amongst professionals for various benefits, such as professional jurisdiction, institutional change and policy influence (Fourcade 2006; Suddaby and Viale 2011; Seabrooke 2014). Transnational professionals - lawyers, accountants, economists, and so forth - are the "preeminent institutional agents of our time" (Scott 2008), critically involved in the reconfiguration of social norms, markets and politics. A key source of this power is professionals' unique transnational resources; they can draw on transnational epistemic authority and their dual role as professionals/institution-builders and national/transnational agents (Kauppi and Madsen 2013; Seabrooke 2014; Dezalay and Garth 2016). In this vein, scholars have stressed the competitive reconfiguration of transnational professionalisation (Fourcade 2006), professional regulation (Arnold 2005; Suddaby, Cooper, and Greenwood 2007), organisational contexts (Faulconbridge and Muzio 2012; Boussebaa, Morgan, and Sturdy 2012), professional market-making (Quack 2007; Dezalay and Garth 2010; Boussard 2016), and professional influence on socio-economic governance (Bötzem 
2008; Cutler 2010; Seabrooke and Tsingou 2015; Mudge and Vauchez 2016). What unites these studies is a simple point: It is imperative to understand transnational professional competition in order to understand transnational professional action, institutions and contexts. The question, then, is how to theorise this professional competition in the transnational space, to which I now turn.

\section{Theories of transnational professional competition}

While a range of empirical studies have emerged recently from a variety of disciplines and traditions, associated developments of theories and concepts specifically for the study of transnational professional competition have lagged behind. That is a shame because transnationalisation - in terms of transience, authority diffusion and governance reconfiguration - requires a fundamental 'rescaling' and 're-tooling' of theories on professional agency and institutions, including regulatory and organisational settings (Faulconbridge and Muzio 2012; Go and Krause 2016b).

Most existing studies have drawn, implicitly or explicitly, on the insights of Pierre Bourdieu and Andrew Abbott, leveraging their analyses of fields and power, ecologies and competition. The heritages from Abbott and Bourdieu have emerged as prominent theoretical levers for transnational professional analysis (Dezalay and Sugarman 1995; Faulconbridge and Muzio 2012). The flexibility and multi-levelled applicability of field and ecology concepts have proven particularly useful for studies of ephemeral transnational spaces. The relational philosophy shared by Abbott and Bourdieu is also particularly relevant for analyses within and across new levels and spaces because of its emphasis that boundaries and levels of analysis are not fixed or assumed, but investigated (Vauchez 2011; Go and Krause 2016a; Buchholz 2016).

However, the two approaches have largely developed in parallel streams. Bourdieu's field theory and reflexive sociology (Bourdieu 1985a, 1985b, 2010; Bourdieu and Wacquant 1992), with structural power dominance at its core, has featured notably in studies on transnational professional elites, often with a focus on lawyers (like Bourdieu himself). Meanwhile, Abbott's ecological sociology (A. Abbott 1988, 2005b), which embraces a more processual symbiotic dynamic of jurisdictional contestation, has inspired work on the transnational organisational context of professional life as well as work on economics and global financial governance. Below, the key dimensions of the two theoretical approaches are briefly outlined ${ }^{1}$, including key social dynamics and

\footnotetext{
${ }^{1}$ This exploration is necessarily limited given the vastness of the theoretical universes of Abbott and Bourdieu and the work building on their insights. The aim here is to outline central features of particular relevance to the discussion of transnational professional competition.
} 
their applicability and application to transnational spaces. Table 1 at the end of the section offers a brief overview of the two approaches.

\section{Fields and transnational professional elites}

The first dominant stream in scholarship on transnational professional competition has drawn extensively on Pierre Bourdieu's field theory. "Fields", Bourdieu's metaphor for social space, are sites of perpetual struggle, divided by class and fraction, and organised along lines of elites/domination and non-elites/subordination. They are semi-autonomous sites "of organized striving” (Martin 2003), structured by distribution of various forms of power resources and personal lifestyles, which shapes the continuous struggles between dominant and dominated groups, typically with the success of the former. Agents of varying type of characteristics were set within these organised, hierarchical spaces, from where his analysis departed. According to Bourdieu, fields help us capture the true, contextual nature of class dynamics and social stratification that simpler analyses had failed to do (Bourdieu 2010).

Professions and professionals were theorised by Bourdieu as agents of class fractions and elites within fields, such as the legal field or the accounting field. These fields contained a distinct set of agents, distinct systems of beliefs among those agents (a view of the social space and its applicable 'rules'), distinct institutions and distinct hierarchies of capital (Bourdieu 1985b, 1985a). Because of these structuring hierarchies, there is a particular emphasis on dominance and power as the preeminent social dynamics in Bourdieu's field theory. The creation of new professions or change in their relative standing in society was, for instance, primarily a consequence of macro-level changes to class/power structures. The emergence of cultural 'consultancy' professions was seen as a strategy for economic elites to reassert their power in the face of socio-economic changes facilitating the spread of university degrees.

Bourdieu's concepts of "habitus" and "capital" fundamentally conceptualise professional life in the field. Habitus is the amalgamation of agents' total prior experience, which produces dispositions guiding their behaviour and interpretations. It is an overarching principle shaping lifestyle, such as the "gentlemanliness" and cultural service orientation of wealth managers (Harrington 2017); a structured and structuring structure and "a general, transposable disposition which carries out a systematic, universal application" (Bourdieu 2010, 166). Capital, a central component in Bourdieu's explanation of the unequal distribution of power that creates the field's dominance dynamic, is a relational good signifying hierarchy; it may be economic (e.g. money), 
cultural (e.g. education), symbolic (e.g. prestige) or social (e.g. network access), with the importance of each of these varying across fields. Capital is not only central in determining the hierarchy within a field but also across fields; the "field of power" is where the meta-capital game is played, with field elites struggling for the hierarchy across fields and types of capital. For instance, Bourdieu argued that French legal elites enjoyed high social standing in contemporary France because of the power of the legal field (Bourdieu 1986).

Bourdieu never theorised transnational fields, but his followers have usefully employed field concepts for transnational studies. In Bourdieu's own work, the field of power - in which struggles among elites of different fields takes place - was always dominated by the state possessing metacapital. The French state played a central coordinating role in his contemporary empirical experience and he held a profound scepticism towards ideas of "globalisation". In this vein, his followers have theorised transnational spaces as fundamentally built upon and intricately linked to national fields (Dezalay and Sugarman 1995). Here, the power of elite legal professionals rested on the ability to successfully broker across national and transnational fields. Kauppi and Madsen have provided a similar theorisation, discussing transnational fields within International Relations governance, security and law as dominated by professional elites leveraging their dual role as national and transnational authorities (Kauppi and Madsen 2013, 2014).

Others have sought to re-tool Bourdieusian field theory more specifically for transnational analysis. Vauchez (2011) and Adler-Nissen (2011) stress the connectedness and homologies of national and non-national spaces, but they also view transnational spaces as uniquely characterised by limited statehood and a weakly differentiated social structure, contested by transnational professionals (cf. also Bigo and Madsen 2011). Here, professional authority in transnational spaces is dependent on national sources of authority, but those sources are not necessarily connected to the nation-state. Similarly, Buchholz specifically theorises the Bourdieusian field for social spaces "beyond the state" (Go and Krause 2016b; Buchholz 2016). She defines these as "globally extended sphere of specialized practice that displays a relatively autonomous logic of competition vis-a-vis other types of fields as well as other field levels within the same realm of practice" (Buchholz 2016, 42). She conceives transnational fields as independent (but not detached) from national fields in terms of both functional autonomy and vertical autonomy. The former distinguishes the unique logics of fields, e.g. the global field of art from the global field of economics, whereas the latter distinguishes global from national levels, e.g. the global field of art from national fields of art. Both are required for the establishment of a truly transnational field. 


\section{Ecologies and transnational professions}

As opposed to the Bourdieusian power emphasis, the use of Abbott's ecological theory in studies of professional competition has conceptualised professional dynamics as equilibrium-based contestations within a symbiotic ecological system. Previous work in the sociology of professions had theorised a processual conformity of professionalization, a linear path of professional development towards a fixed outcome of associations, licensing and state-granted monopoly (A. Abbott 1988, 1-2). Abbott instead sought to theorise the jurisdictions of professions in the context of a system of interlinked ecologies, his metaphor for social space. Ecologies are a set of social relations constraining and influencing each other, comprised of three main components: actors (professions), locations (jurisdictions) and the relations associating the two (A. Abbott 2005b). The relational process, ligation, which constitutes all three, is preeminent, in accordance with Abbott's relational and processual ontology. Professional ecologies are not given social entities; they are only "made" through the dynamic of establishing relations between the ecological elements, including other professions, tasks, the state and clients. "Creating a psychiatric approach to shell shock in World War I, for example, redefined who psychiatrists were and what shell shock was more than it defined a relation between a preexisting group and a given task" (A. Abbott 2005b, 248-49).

Like Bourdieu, Abbott emphasised the adversarial nature of professional life, but he saw competition as primarily a symbiotic dynamic. For Abbott, the contestation of professions did not necessarily lead to dominance/subordination dynamics, but rather to punctuated equilibria through ecological competition. Using an economic analogy, Abbott's was an image of quasi-perfect competition in the neoclassical sense, in which "the equilibrating forces prevail, assuming that no profession delivering bad services can stand indefinitely against competent outsiders, however powerful it may be" (A. Abbott 1988, 135), while Bourdieu emphasised an imperfect competition of strong oligopolies and tycoon empires. That is not to say Abbott did not recognise or emphasise professional power dominance; rather, he saw the distinction as a dimension of time-scales and degree $^{2}$.

In ecological theory, dominant professional groups are relatively marginal incidence. The ability to resist professional competition under the systemic pressures from adjacent professions, the state and the public, might be present in the short term, but symbiotic contestation is the preeminent

\footnotetext{
${ }^{2}$ In his characterisation, professional jurisdictions are negotiated in workplaces over two- to three year periods, in public over ten- to twenty-year periods, and in the law over twenty- to fifty-year periods - which he suffices for "long term" or the time scales in which equilibrating forces dominate (A. Abbott 1988, 135).
} 
long-term dynamic (A. Abbott 1988, 136-42). The ecological system, for Abbott, provided crucial friction against lasting power: "Equilibrium levels of dominance may take so long to achieve that other perturbations prevent their ever arriving" (A. Abbott 1988, 109). For instance, while lawyers were at one point able to deter accountants from infringing on its tax jurisdiction due to the legal professions' relative public standing, systemic forces have eventually helped foster a shared settlement (ibid.).

Abbott also never theorised transnational dynamics, but the ecological approach has still played a central role in the literature on transnational professional competition. Abbott's analysis relied on cross-national comparison, "professions compete within nations" (A. Abbott 1988, 193), and the nation-state was conceptualised as the proper context and a crucial orchestrator of professional contexts. The American state played a smaller, different role in the ecological system than the French state, but both remained central. To the author's knowledge, there have not been specific attempts to re-tool Abbott's ecological theory for transnational professional spaces, but his concepts have been applied there. Fourcade (2006) discusses a transnational ecological analyses that emphasises the emergence beyond the state of professional free trade, of professional jurisdictions, and of creative destruction of professional markets. The ecological model, she argues, "lends itself naturally to such an extension" because of its "focus on the interactions between the work of professionals, its knowledge or discursive base, and the jurisdictional domain they claim control upon" (p. 155-6). Seabrooke and Tsingou (2009b, 2015) offer similar arguments, but in the empirical context of changing global governance. For them, cross-cutting strategies within the linked ecologies system, such as 'hinges' and 'avatars' (A. Abbott 2005b), are required to understand professional influence in transnational policy environments. Other studies of transnational ecologies in this vein have examined global development policy (Stone 2013), macroprudential global financial regulation (Baker 2013), economic power and policy (Hirschman and Berman 2014; Farrell and Quiggin 2017), and professionals in global professional services firms (Faulconbridge and Muzio 2012; Muzio et al. 2016; Boussard 2016).

Seabrooke (2014) specifically conceptualises transnational "epistemic arbitrage" as a key professional strategy within the ecological system, a tactic particularly relevant to transnational space because of the prevalence of "structural holes" (Burt 1992) and knowledge struggles in "thinly networked' sites. Similarly, Adams (2016) highlights the utility of Abbott's theories for the study of self-regulation of transnational professional work. The ecological approach, she argues, allows the researcher to focus on "both state actor and professional interests and concerns, and consider when 


\section{DRAFT}

and how these interests intersect" (p. 4), providing the proper middle ground between theories overemphasising professional demands and approaches neglecting non-state activity and interests.

Table 1. Field and ecology approaches to transnational professional competition

\begin{tabular}{|c|c|c|}
\hline $\begin{array}{ll} & \text { Approach } \\
\text { Element } & \end{array}$ & Ecologies & Fields \\
\hline Key authors & $\begin{array}{l}\text { Abbott, Seabrooke, } \\
\text { Fourcade }\end{array}$ & $\begin{array}{l}\text { Bourdieu, Dezalay, Garth, } \\
\text { Kauppi, Madsen }\end{array}$ \\
\hline Social space metaphor & Ecology & Field \\
\hline Key actors & $\begin{array}{l}\text { Transnational professions } \\
\text { and professionals }\end{array}$ & $\begin{array}{l}\text { Transnational professional } \\
\text { elites }\end{array}$ \\
\hline Key social dynamic & Competition & Domination/subordination \\
\hline Empirical focus & $\begin{array}{l}\text { Economics, financial } \\
\text { governance, professional } \\
\text { services }\end{array}$ & Legal elites, security elites \\
\hline
\end{tabular}

Fields and ecologies, then, offer particularly fruitful lenses for the study of transnational professional competition. However, there remains relatively little scaffolding of field and ecology theories and concepts for the specific application to transnational professional competition, and very little interaction amongst the two schools of thought. The literatures have dealt with relatively similar empirical topics, but the distinct theoretical approaches and language have also ensured separation. Field theory has featured more prominently in International Relations' "sociological turn" (AdlerNissen 2013) and in International Political Sociology (Bigo and Madsen 2011), with ecological studies clustering in Organisation and Management Studies (Suddaby and Muszio 2015) as well as International Political Economy (Seabrooke and Tsingou 2015; Seabrooke and Henriksen 2017). Although central differences will and should remain, an examination of prospects for synthesis can help conceptualise common ideas and outline potentials for learning. Thus, the next section seeks to elaborate the points of contention and prospects for convergence. 


\section{Contention and convergence}

Why has there been relatively little exchange between field and ecology studies of transnational professional competition, and what are the prospects for finding common ground across the two streams? Such a diagnosis is needed in order to assess the potential points of mutual learning, which I will argue has the potential to enhance understanding of transnational professional competition. Thus, this section outlines the main points of contention and prospects for convergence between the field and ecology streams, before moving towards a broader discussion of points of learning ${ }^{3}$.

\section{Points of contention}

Based on the field and ecology literatures, I identify three key differences causing fragmentation: social dynamics, embeddedness of transnational actors, and methods. First, the social dynamics of the two approaches has contributed to a substantial chasm. Transnational professional scholarship in the Bourdieusian vein has emphasised a more structurally-oriented and contingent agency, as well as power across fields, as opposed to Abbottian studies in which "[ $\mathrm{t}] \mathrm{h}$ he focus is on the agent's personal skills or creativity" (Dezalay and Garth 2016, 190). Bourdieu's French and Abbott's American heritage taught widely different social dynamics, which have trickled down to transnational professional competition studies. Bourdieu's academic upbringing always maintained a close relationship between sociology and political science; French sociology favours structural dominance dynamics that mirror the French public and political system (Kauppi 2013, 4). Meanwhile, Abbott's American academic lineage of Chicagoan population ecology studies emphasise an evolutionary, liberal competition dynamic that are prevalent in American social views (Liu and Emirbayer 2016, 64-65). In consequence, the field scholarship has emphasised class, stratification, power, structural dominance and subordination, while ecological analysis has focused on symbiotic equilibrium-based contestation from a process perspective.

Second, the view of the link between national and transnational spaces is a point of contention. While both streams recognise and study transnationally-specific professional competition, the degree to which such competition is decoupled from national power sources and spaces is disputed. Whereas field scholars have emphasised the embeddedness of transnational professional power in national institutions, ecology scholars have maintained that there is a greater detachment of transnational

\footnotetext{
${ }^{3}$ As above, this discussion is necessarily limited given the vastness of the theoretical universes of Abbott and Bourdieu and the work building on their insights. Once more, the aim here is to outline central features of relevance to the discussion of transnational professional competition. For further examinations, see Liu 2015; Liu and Emirbayer 2016.
} 
actors, who are relatively 'free' from national reigns. In this vein, Dezalay and Garth note that the power of transnational legal elites "is embedded in the long-term construction and structure of these elite professional strategies around the state" (Dezalay and Garth 2016, 202). Meanwhile, Seabrooke argues that the uniqueness of transnational spaces is that it "requires the actors operating in a different social space and reconfiguring how they work rather than replicating their national institutions or changing their own to reflect other national institutions." (Seabrooke 2014, 55). The autonomy of transnational action, the level of embeddedness of transnational professionals in national spaces, thus, is differently understood.

Third, and because of these substantive differences, the differing methods used under each approach have caused separation. Different methods leads scholars to different types of answers to similar questions, and they build competing vocabularies that hinder cross-discussion. Thus, while Bourdieusian analyses of transnational professional spaces have notably employed Correspondence Analysis (CA), Abbottians have rather used Social Network Analysis (SNA) and Sequence Analysis (SA). Importantly, all of these are descriptive, spatial analytical methods, ways to understand social spaces by characterising and relating the actors involved (Ellersgaard et al. 2017), but they have tended to be associated with one or the other stream.

CA provides a structural mapping of social spaces by identifying similar groups of individuals, which has provided Bourdieusians the ability to visualise key orders of difference within a field (Bourdieu and Wacquant 1992; Lebaron 2008; Ellersgaard et al. 2017). SNA provides a similar picture of social space but it is based on connections between individuals rather than their individual attributes, and has primarily been used to show Abbottian professional competition in transnational spaces (Henriksen and Seabrooke 2016; Seabrooke and Henriksen 2017). SA also provides a visualisation of social spaces, but here the emphasis is on the trajectories of individual characteristics, such as careers or other life states. Like SNA, SA has most widely been used in ecology studies (A. Abbott and Tsay 2000; Blanchard 2011; Seabrooke and Nilsson 2015). The 'siloing' caused by this strict division - CA used in field studies and SNA/SA used in ecology studies of transnational professional competition - provides another point of separation.

\section{Prospects for convergence}

Drawing from the ongoing field-ecology debates, I also identify three key points for the prospects for convergence: scientific philosophy, space diversity and origins of change. First, fragmentation has occurred despite a rich commonality in terms of scientific philosophy between the field and ecology 
approaches to transnational professional competition. Although Abbott and Bourdieu themselves highlighted tensions between their approaches ${ }^{4}$, there are a number of key similarities (Liu and Emirbayer 2016). Fields and ecologies share a relational philosophy (Emirbayer 1997) ${ }^{5}$ and a preoccupation with social spaces. Such relational studies of spaces understand the social not as substantive entities but as links and interactions, locations and position-taking, allowing us to "see" social interactions and structures (Emirbayer 1997).

Fields and ecologies also share an emphasis on structural isomorphism, the convergence of individual action and characteristics given similarity of (transnational) environments. Furthermore, both field and ecology studies are preoccupied with temporal dynamics, i.e. how transnational spaces change over time. They also have a social psychology view of normality vs. rupture; actors typically act out of practice or habit, but in times of crisis, there is greater scope for radical change. In short, field and ecology theories may "speak different languages but nonetheless have common genes in their bodies" (Liu and Emirbayer 2016, 68).

Second, prospects for convergence can be found in the view of diversity in social spaces. While in general ecological models are more homogeneous and field models more heterogeneous in terms of the actors involved (Liu and Emirbayer 2016, 70), this has not necessarily been the case with scholarship on transnational professional competition. Like field studies, ecology studies have emphasised a broad range of different actors. For instances, Mudge and Vauchez' (2016) field study of the European Central Bank analyses both international financial institutions, professional economists and European politicians, but similarly Stone's (2013) ecology study of global development examines international financial institutions alongside university researchers and think tanks. Reasonable questions remain on the convergence of interaction diversity, as ecology studies have tended to focus on symbiotic contestations, but there is an emerging convergence in terms of actor diversity. One reason for this convergence is Abbott's elaboration of the linked ecologies system. Linked ecologies studies such as Stone's feature not only inter-professional competition judged by a quasi-external "audience" (as in earlier ecological work) but models a range of social

\footnotetext{
${ }^{4}$ In Bourdieu's words, the professions analyses of Abbott and others was too simplistic: "[O]ne must go further and call into question not only classifications of occupations (. . .) but the very concept of occupation itself, or of profession (Bourdieu and Wacquant 1992, 242). Abbott, considering Bourdieu's view of the social world in relation to his own, also emphasised their differences: "It should thus be apparent that there is not so much affinity between Bourdieu's conception of social structure and my own as there is a kind of accidental resemblance" (A. Abbott 2005a).

${ }^{5}$ Bourdieu's field theory is markedly relational, and Bourdieu himself has been described as a "pioneer of relational sociology' (Bourdieu 2010, xxiii); however, there have been questions about Bourdieu's relational inclination given the structural emphasis of his analyses (e.g. Dépelteau 2008).
} 
relations - across politics, academia and the professions, etc. - within the interdependent ecological system.

The linked ecologies framework also bridges to the third point, namely that recent scholarship on transnational professional competition has aligned fields and ecologies more closely in terms of the origins of change. Historically, ecological models have seen social action originate exclusively within the ecology, e.g. a profession, leaving little scope for external influence. Meanwhile, externally spurred change has been central to Bourdieusian field scholarship, where fields are always closely connected to other fields where social action can cause change. However, in Abbott's linked ecologies framework, changes in the system are not exclusively results of endogenous change within the ecology; rather, change is mediated through the integrated ecological system, but can originate outside of the ecology as well. Here, successful professional strategies such as 'hinges' and 'avatars' bridge across ecologies, and ecologies can potentially overlap and subcategorise more fluidly. This is a step towards (although not a full resolution of) convergence on origins of change. In this vein, recent scholarship on transnational professional competition has leveraged the linked ecologies framework to expand on change dynamics within and across ecologies. Fourcade's (2006) study of the economics profession, for instance, identifies its global institutionalisation as a result of interecological strategies of rhetoric, politics and transnational linkages, while Farrell and Quiggin (2017) conceptualise the deep and strategic overlap between the economics profession and economic policymaking.

Given these prospects for convergence, as well as the points of contention, a cautiously budding literature has sought to bridge the two streams in the study of transnational professional competition. A notable volume of work has utilised Bourdieusian concepts and theory in the study of transnational professions, while also drawing on Abbott's work (Quack 2007; Gracia and Oats 2012; Ashley and Empson 2016; Harrington 2017). These new developments within the literature offer unique potential and prospects. As Saks notes, they underline "the present dynamism of theoretical analyses of professions" (Saks 2016, 182). At the other end of the spectrum, there has been some interaction of Abbott theorists with Bourdieusian transnational elite scholarship (e.g. Seabrooke and Tsingou 2009a). Furthermore, beyond the transnational professional competition literature specifically, Liu and Emirbayer (2016) have proposed a stronger theoretical dialogue and specific issues for dialogue between field and ecology scholars. However, such cross-fertilization within and across scholarship on transnational professional competition specifically remains underdeveloped, 
and an examination of these debates and the specific potentials for learning across field and ecology studies is warranted.

\section{Points of learning}

Mutual learning across field and ecology literatures on transnational professional competition has the potential to enhance understanding of specifically transnational professional relations, institutional change, social contexts and social structures. It also has the potential to address points of contention and exploit points of convergence. In this section, I draw out proposals for mutual learning that can contribute to advancing studies of transnational professional competition, building on the discussion above and on other existing literature on the field and ecology paradigms, in particular Liu and Emirbayer (2016). I identify four specific points of cross-learning that may inform future research within and across the streams on the specific context of transnational professional competition. First, a broadened conceptualisation of social dynamics. Second, the layering of field and ecology concepts. Third, an emphasis on the wider socio-political-cultural context of transnational professional action. Fourth, methodological cross-fertilization. Table 2 at the end of the section offers an overview of the proposed points of learning.

First, there is potential for learning through a broadened conceptualisation of social dynamics in both streams. The emphasis on dominance and competition, respectively, in the field and ecology literatures, overly restrains empirical inquiry in transnational analyses, given the novelty of social spaces and the indeterminacy of professional relations here. Focus on diversity of social dynamics in studies of transnational professional competition would align better with actor diversity in field and ecology theories and would help make social relations more attuned to transnational reality (Liu 2015; Seabrooke and Henriksen 2017). The key point is to refine the spectrum of dynamics beyond simple dominance/subordination or competition. Such an approach also aligns well with the relational heritage of both Abbott and Bourdieu, by which the specific social relations should be subject to emergentist inquiry, rather than global assumptions of a dominant logic. This does not mean entirely re-casting field dynamics as cooperation; rather, the focus should be on broadening the possible sources of transnational professional relations and power.

Kauppi and Madsen (2013, 6-9), for instance, refresh Bourdieusian power concepts for transnational professional elites, including expert power, cultural power and network power as transnationally constructed. They also draw on Peter Haas' work on “epistemic communities” (Haas 1992) in conceptualising networks as a fundamentally cooperative source of transnational power. 
Eyal (2013), advancing a critique of Abbott's power concept, argues that professional power must capture not just monopoly control of professional tasks but rather a "dynamic interdependence between monopoly, autonomy, generosity, and coproduction" (p.877), including the ability to leverage networked cooperation of clients and other parties. Seabrooke and Henriksen (2017) also advance a diverse set of professional-organisational strategies for transnational spaces that go beyond logics of command, such as 'decoupling' professional claims from organisational sites and 'yoking' of boundaries around new professional issues.

More generally, a broadened conceptualisation of social dynamics requires both field and ecology scholars to pay attention to a broader range of interaction concepts, within and across transnational professional spaces, such as exchange and boundary work (Liu 2015; Liu and Emirbayer 2016). In this context, it is also worth recharging Abbott's and Bourdieu's own analyses of diversity in their theories. Abbott's original point that, “[o]f course the professions are not internally homogeneous" (A. Abbott 1988, 115), along with his recent elaborations on linked ecologies, lends emphasis to more diverse view of social dynamics. The linked ecologies approach allows us to "relax 'professions' to 'professionals"' (Seabrooke 2014, 54), but also to conceptualise other actors (e.g. state and public actors) as potential ecologies themselves, or as mixing within and across ecologies, e.g. through the 'hinge' and 'avatar' strategies (A. Abbott 2005b). Abbott's hinges and avatars, for instance, provide useful examples of competitively-based social relations that result in diverse outcomes across diverse social spaces.

In this vein, some ecology scholars have effectively shown how such ecological interactions can generate dynamics of exchange and cooperation across diverse transnational units (Seabrooke and Tsingou 2009b, 2015; Mennicken 2010; Stone 2013). Just as "[p]rofessional fields can be in competition with non-professional fields" (Schinkel and Noordegraaf 2011, 87), transnational professional ecologies can be in competition with non-professional ecologies. Another example here is Oats and Gracia (2012), who invoke Abbott's concept of professional jurisdictional boundaries to frame a Bourdieusian analysis of professional boundary work across a modern tax field that is "overlaid and intertwined with a number of other social and professional fields including the accounting, political, bureaucratic and juridical fields" (p. 6). Such a broadening of social dynamics also has potential to help address contention over the (dis)embeddedness of transnational agents in field and ecology studies; allowing for a broader range of social interactions opens up space for national and non-national sources of power to play different roles across different spaces and empirical cases. 
Second, there is potential for learning through the layering of field and ecology concepts. The theorisation of professional dynamics in transnational spaces requires attention to the uniqueness of institutional change and stability "beyond the state", but the field and ecology perspectives have conceptual strengths for different such changes. One advantage of Bourdieusian field studies is the attention to behavioural sources of professional agency and field-level change/stability in the competition across distinct fields. In comparison, ecological scholarship's intricate theorisation of the meso-level dynamics of jurisdictional change is favourable for analysis of such transnational contexts. Thus, the layering of ecology concepts in Bourdieusian fields and vice-versa may provide a stronger total understanding of transnational institutional change. This would further support convergence of field and ecology studies in terms origins of change, by paying close attention to how (institutional) change originates and mediates across and within social spaces.

Schinkel and Noordegraaf (2011) specifically seek to bridge the works of Abbott and Bourdieu on professionals in order to understand institutional power struggles. They address Bourdieu's critique of the professions concept, which had, in his view, "been uncritically smuggled into scientific language"; rather than accept the professions as objects of study per se, there was a need to "take seriously the work of aggregation and symbolic imposition that was necessary to produce it" (Bourdieu and Wacquant 1992, 242-43). Schinkel and Noordegraaf thus re-conceptualise professionalism, as theorised by Abbott, as Bourdieusian symbolic capital, locating professional competition within a broader field structure. This allows them to refocus the analysis towards wider field-level institutional struggles involving professional behaviour and norms as power resources. Other scholars have applied Abbott's ecological theories of professional jurisdiction to conceptualise institutional change within and across established (organisational) fields (Suddaby and Viale 2011; Hasselbalch 2016). Seabrooke and Henriksen (2017) also combine ecology and field scholarship in theorising transnational professional competition, arguing that this allows for an understanding of "how professionals and organizations take positions on particular issues relative to their peers (as in a field), as well as the character of the ties between those involved on the transnational issues" (p.18).

Third, there is potential for learning through an emphasis on the wider socio-political-cultural context of study. Because of the novelty, transience and 'thinness' of transnational spaces, there is a need for a particular attention to the wider social, political and cultural context of professional competition, as analyses cannot rely on established models of such context. Studies of transnational social contexts must take account of "the broader sociological picture" (Dezalay and Madsen 2017, 51). This point is relevant at both the theoretical and the more practical level. At the theoretical level, 
one strength from the Bourdieusian analysis that has typically eluded ecological studies, but often also field analysis, is the consistent application of "second order" reflexivity (Bourdieu and Wacquant 1992). Reflexivity requires the researcher to objectivise the empirical object of study, critically assessing definitions and discourses, including the researcher's own. While reflexive sociology is at the heart of the Bourdieusian heritage, it has only featured marginally in studies on transnational professional competition (Madsen 2011).

The case for reflexivity is that, by treating the object of study and the study itself as sociological phenomena, we can transparify and conceptualise ongoing struggles about how to conceptualise transnational spaces. This transparency in turn allows for learning and crosscollaboration by laying bare the assumptions and contextual choices made by the researcher about transnational professional competition. Centrally, reflexivity can strengthen research impact by addressing the wider context of study, allowing for re-tooling of the analysis for the specific empirical content (Leander 2002). As Bourdieu noted, the reflexive nature of the field concept means "that it promotes a mode of construction that has to be rethought anew every time" (Bourdieu and Wacquant 1992, 110). In the transnational professional context, this means investigating organisational, institutional and structural logics as well as professional ones, and paying attention to the "the hidden processes and structures which have made possible [the] projection of power and interest under the guise of, for example, institutions or professionalism" (Kauppi and Madsen 2014, 326). Eyal's (2013) analysis of the construction of the 'field' of autism treatment is one example, which builds on but goes beyond an Abbottian approach, makes visible the historical struggles within and across diverse ecologies of experts, clients, state actors, etc.

At the more practical level, an emphasis on the wider socio-political-cultural context of study implies a broadening of the study of transnational professional competition from purely professional properties to incorporate the institutional environment and socio-economic impacts. Various literature reviews have highlighted the importance of addressing the "socio-historical and cultural context to professions" (Adams 2015), the "professions and professional organization in the broader political economy" (Brock, Leblebici, and Muzio 2014), and investigating professionals in relation to globalisation (Carter, Spence, and Muzio 2015). The new institutionalist turn in the professions literature specifically seeks to add to Abbottian scholarship by addressing the role of professionals in reworking key (transnational) institutions (Muzio, Brock, and Suddaby 2013). Such an approach allows researchers to pay attention to the specifically transnational organisational contexts of professionals, such as large global professional services firms (Boussebaa, Morgan, and Sturdy 2012) 
as well as new modes of 'soft', normative transnational professional closure (Boussard 2016). An institutionalist emphasis can also enabling a more detailed conceptualisation of the mediation and refraction of socio-political and cultural change through social spaces (Scott 2008; Leicht and Fennell 2008; Muzio, Brock, and Suddaby 2013).

Finally, there is potential for learning through greater cross-fertilization of methods. Dominant methods for analysing transnational professional spaces and individual characteristics Correspondence Analysis, Social Network Analysis and Sequence Analysis - are all useful descriptive methods that can shed light on social structures. But the 'siloing' of methods in the streams has inhibited scholars new and useful descriptions of the specific social structure of transnational spaces that are particularly thinly occupied. Paradoxically, despite the Abbottians being cast as narrowly concerned with "the sociological properties of groupings" (Kauppi and Madsen 2017, 164), it is the more structurally-oriented Bourdieusians that have tended to emphasise the individual characteristics of agents using Correspondence Analysis rather than social relational structure through Social Network Analysis - and vice-versa. Thus, there is potential to strengthen scholarship within each stream by reaching across. In this vein, recent scholarship on elites and fields has bridged into Sequence Analysis (Blanchard, Dudouet, and Vion 2015; Ellersgaard et al. 2016) and Social Network Analysis (Powell et al. 2005; Savage and Williams 2008). Similarly, the vast migration of Bourdieusian concepts into, e.g. Organisation Studies (Emirbayer and Johnson 2008) and International Relations (Adler-Nissen 2013), where ecological studies are well-known, also hints at the potential of Correspondence Analysis for ecological studies of transnational professional competition. A more widespread cross-learning on methods would help ecology scholars map patterns of transnational professional relationships and orders of power and help field scholars discover "structural holes" (Burt 1992) and inter-personal social structures amongst transnational elites. Furthermore, methodological cross-fertilization can help build common vocabularies, allowing researchers across the streams to communicate more easily about results. 
Table 2. Proposed points of learning for transnational professional competition studies

\begin{tabular}{|c|c|c|c|c|}
\hline $\begin{array}{l}\text { Point } \\
\text { Element }\end{array}$ & $\begin{array}{l}\text { Social dynamics } \\
\text { spectrum }\end{array}$ & Layering concepts & Wider context & Methods \\
\hline $\begin{array}{l}\text { Source of } \\
\text { potential }\end{array}$ & $\begin{array}{l}\text { Exaggerated emphasis } \\
\text { on one social } \\
\text { dynamic, tendency to } \\
\text { analytical } \\
\text { determinism }\end{array}$ & $\begin{array}{l}\text { Capitalising on varying } \\
\text { strengths, } \\
\text { accommodating } \\
\text { weaknesses }\end{array}$ & $\begin{array}{l}\text { Importance of social, } \\
\text { political and cultural } \\
\text { contexts in transient } \\
\text { spaces }\end{array}$ & $\begin{array}{l}\text { Siloing hinders } \\
\text { valuable } \\
\text { empirical insights } \\
\text { in each stream }\end{array}$ \\
\hline $\begin{array}{l}\text { Specific } \\
\text { transnational } \\
\text { significance }\end{array}$ & $\begin{array}{l}\text { Novelty of } \\
\text { transnational spaces } \\
\text { and indeterminacy of } \\
\text { professional relations }\end{array}$ & $\begin{array}{l}\text { Micro-level behavioural } \\
\text { and meso-level } \\
\text { jurisdictional sources of } \\
\text { transnational } \\
\text { institutional change }\end{array}$ & $\begin{array}{l}\text { Understanding of } \\
\text { unique transnational } \\
\text { context of professional } \\
\text { competition }\end{array}$ & $\begin{array}{l}\text { Description of } \\
\text { specific social } \\
\text { structure of } \\
\text { transnational } \\
\text { spaces }\end{array}$ \\
\hline $\begin{array}{l}\text { Proposed } \\
\text { learning }\end{array}$ & $\begin{array}{l}\text { Broadened conception } \\
\text { of social dynamics } \\
\text { Diversity of actors } \\
\text { and relations in social } \\
\text { spaces }\end{array}$ & $\begin{array}{l}\text { Layering field and } \\
\text { ecology theories and } \\
\text { concepts }\end{array}$ & $\begin{array}{l}\text { Sociological } \\
\text { reflexivity } \\
\text { Institutionalist } \\
\text { emphasis }\end{array}$ & $\begin{array}{l}\text { Use of methods } \\
\text { across streams }\end{array}$ \\
\hline $\begin{array}{l}\text { Provides } \\
\text { better } \\
\text { understanding } \\
\text { of }\end{array}$ & $\begin{array}{l}\text { Specifically } \\
\text { transnational } \\
\text { professional relations }\end{array}$ & $\begin{array}{l}\text { Specifically } \\
\text { transnational } \\
\text { institutional change }\end{array}$ & $\begin{array}{l}\text { Specifically } \\
\text { transnational contexts } \\
\text { of professional } \\
\text { competition }\end{array}$ & $\begin{array}{l}\text { Specifically } \\
\text { transnational } \\
\text { social structures }\end{array}$ \\
\hline Examples & $\begin{array}{l}\text { Kauppi and Madsen } \\
\text { 2013; Eyal 2013; Liu } \\
\text { 2015; A. Abbott } \\
\text { 2005b; Seabrooke } \\
2014\end{array}$ & $\begin{array}{l}\text { Schinkel and } \\
\text { Noordegraaf 2011; } \\
\text { Suddaby and Viale } \\
\text { 2011; Hasselbalch 2016; } \\
\text { Seabrooke and } \\
\text { Henriksen } 2017\end{array}$ & $\begin{array}{l}\text { Madsen 2011; Eyal } \\
\text { 2013; Kauppi and } \\
\text { Madsen 2017; Daniel } \\
\text { Muzio, Brock, and } \\
\text { Suddaby } 2013\end{array}$ & $\begin{array}{l}\text { (Blanchard, } \\
\text { Dudouet, and } \\
\text { Vion 2015; } \\
\text { Ellersgaard et al. } \\
\text { 2017; Powell et } \\
\text { al. 2005; Savage } \\
\text { and Williams } \\
\text { 2008) }\end{array}$ \\
\hline
\end{tabular}




\section{Conclusions}

This paper has reviewed existing approaches to the study of transnational professional competition and drawn out proposals for mutual learning at the intersection of the field and ecology schools. In particular, the paper has identified potential in a broadened conceptualisation of social dynamics, the layering of field and ecology concepts, an emphasis on the wider socio-political-cultural context of transnational professional action, and methodological cross-fertilization. The paper has argued that a closer exchange between field and ecology scholarship around these points of learning has the potential to address points of contention and exploit points of convergence. More importantly, such cross-learning can enhance understanding of specifically transnational professional relations, institutional change, social contexts and social structure.

First, to understand the transnational specificity of professional relations, analyses require a greater flexibility in social dynamics, reflecting the fundamentally ambiguous and "up for grabs" nature of transnational spaces. Thus, analyses in the tradition of Bourdieu and Abbott would benefit from broadening and re-tooling the conception of social relations at play in transnational professional competition, such as re-casting power concepts and allowing scope for processes of exchange and boundary work. This would strengthen analyses by providing accounts that are able to encompass and question a greater variety of professional relations, in alignment with transnational reality. Second, by layering field and ecology concepts, studies of transnational professional competition can make better sense of the micro-level behavioural and meso-level jurisdictional sources of transnational institutional change. Third, in order to understand transnational professional contexts, critical attention is required to the social, cultural, political and historical dimensions of the research object. In this vein, studies would benefit from an inclusion in the analytical process of sociological reflexivity and institutionalist inquiry. This would help to ensure that transnational spaces and dynamics are "thought anew" and that two-way relationships between professionals, researchers and institutional contexts are understood. Fourth, methodological cross-fertilization will help field and ecology researchers "see" transnational social structures through descriptions that support the specific theoretical approaches.

In making these points, the paper has responded to recent calls for a transnationalisation of scholarship on professionals and their institutional context (Faulconbridge and Muzio 2012) and the theories used to investigate it (Seabrooke 2014; Go and Krause 2016b). The specific proposals advanced here build on recent literature on fields and ecologies (Liu 2015; Liu and Emirbayer 2016) and on transnationalisation of professional field and ecology concepts (Fourcade 2006; Seabrooke 


\section{DRAFT}

and Tsingou 2009b; Vauchez 2011; Adler-Nissen 2013; Go and Krause 2016b). Whether studying transnational professional competition from field or ecology approaches, from Sociology, Organisation and Management Studies, International Relations or International Political Economy, a closer engagement across holds potential to advance this common area of inquiry. By highlighting differences, similarities and points of mutual cross-learning, this paper has contributed to building a common vocabulary for discussing current and future research within and across the two main approaches. This will allow scholars not only to speak more closely around the same topics, but more importantly to ask better questions about how to study and understand professional competition in transnational spaces. 


\section{Bibliography}

Abbott, Andrew. 1988. The System of Professions: An Essay on the Division of Expert Labor. Chicago: University Of Chicago Press.

—. 2005a. "Ecologies and Fields." Section on Bourdieu omitted from "Linked Ecologies" (2005). http://home.uchicago.edu/aabbott/Papers/BOURD.pdf.

—. 2005b. "Linked Ecologies: States and Universities as Environments for Professions." Sociological Theory 23 (3): 245-274.

Abbott, Andrew, and Angela Tsay. 2000. "Sequence Analysis and Optimal Matching Methods in Sociology: Review and Prospect." Sociological Methods \& Research 29 (1): 3-33. doi:10.1177/0049124100029001001.

Abbott, Kenneth W., and Duncan Snidal. 2009. "The Governance Triangle: Regulatory Standards Institutions and the Shadow of the State." The Politics of Global Regulation 44. https://www.researchgate.net/profile/Kenneth_Abbott/publication/228677087_The_governa nce_triangle_regulatory_standards_institutions_and_the_shadow_of_the_state/links/00b495 37fe7e97835f000000.pdf.

Adams, Tracey L. 2015. "Sociology of Professions: International Divergences and Research Directions." Work, Employment \& Society 29 (1): 154-165.

. 2016. "Self-Regulating Professions: Past, Present, Future." Journal of Professions and Organization, October, jow004. doi:10.1093/jpo/jow004.

Adler-Nissen, Rebecca. 2011. "On a Field Trip with Bourdieu.” International Political Sociology 5 (3): $327-330$.

—., ed. 2013. Bourdieu in International Relations: Rethinking Key Concepts in IR. The New International Relations. New York: Routledge.

Arnold, Patricia J. 2005. "Disciplining Domestic Regulation: The World Trade Organization and the Market for Professional Services.” Accounting, Organizations and Society 30 (4): 299-330. doi:10.1016/j.aos.2004.04.001.

Ashley, Louise, and Laura Empson. 2016. "Understanding Social Exclusion in Elite Professional Service Firms: Field Level Dynamics and the "professional Project." Work, Employment and Society, February, 095001701562148. doi:10.1177/0950017015621480.

Baker, Andrew. 2013. "The New Political Economy of the Macroprudential Ideational Shift." New Political Economy 18 (1): 112-39. doi:10.1080/13563467.2012.662952. 
Bigo, Didier, and Mikael R. Madsen. 2011. "Introduction to Symposium 'A Different Reading of the International': Pierre Bourdieu and International Studies: A Different Reading of the International." International Political Sociology 5 (3): 219-24. doi:10.1111/j.17495687.2011.00131.x.

Blanchard, Philippe. 2011. "Sequence Analysis for Political Science.” In APSA 2011 Annual Meeting Paper. http://papers.ssrn.com/sol3/papers.cfm?abstract_id=1902086.

Blanchard, Philippe, François-Xavier Dudouet, and Antoine Vion. 2015. "Le Cœur Des Affaires de La Zone Euro." Cultures \& Conflits 98.

Bötzem, Sebastian. 2008. "Transnational Expert-Driven Standardisation-accountancy Governance from a Professional Point of View." In Transnational Private Governance and Its Limits. London: Routledge, 44-57. https://ecpr.eu/Filestore/PaperProposal/7e18fd9f-c6d4-4ea3aceb-fda585ba234f.pdf.

Bourdieu, Pierre. 1985a. "The Genesis of the Concepts of Habitus and of Field." Sociocriticism 2: $11-24$.

. 1985b. "The Social Space and the Genesis of Groups." Theory and Society 14: 723-44.

1986. "La Force Du Droit: Elements Pour Une Socioligie Du Champ Juridique.” Actes de La Recherche En Sciences Sociales 64: 3-19.

- 2010. Distinction. 1 edition. London: Routledge.

Bourdieu, Pierre, and Loïc Wacquant. 1992. An Invitation to Reflexive Sociology. Chicago: University of Chicago Press.

Boussard, Valerie. 2016. “A New Model of Professions - When Transnational Financial Services Challenge the Sociology of the Professions." Draft paper for "Networks in Finance." Alliance Manchester Business School.

Boussebaa, Mehdi, Glenn Morgan, and Andrew Sturdy. 2012. "Constructing Global Firms? National, Transnational and Neocolonial Effects in International Management Consultancies." Organization Studies 33 (4): 465-486.

Brock, D. M., H. Leblebici, and D. Muzio. 2014. "Understanding Professionals and Their Workplaces: The Mission of the Journal of Professions and Organization." Journal of Professions and Organization 1 (1): 1-15. doi:10.1093/jpo/jot006.

Buchholz, Larissa. 2016. "What Is a Global Field? Theorizing Fields beyond the Nation-State." The Sociological Review Monographs 64 (2): 31-60. 
Burt, Ronald S. 1992. Structural Holes: The Social Structure of Competition. Cambridge, MA: Harvard University Press. http://www.hup.harvard.edu/catalog.php?isbn=9780674843714.

Carter, Chris, Crawford Spence, and Daniel Muzio. 2015. "Scoping an Agenda for Future Research into the Professions.” Edited by Professor Chris Carter, Professor Crawford Sp. Accounting, Auditing \& Accountability Journal 28 (8): 1198-1216. doi:10.1108/AAAJ-09-2015-2235.

Cutler, A. C. 2010. "The Legitimacy of Private Transnational Governance: Experts and the Transnational Market for Force." Socio-Economic Review 8 (1): 157-85. doi:10.1093/ser/mwp027.

Dépelteau, François. 2008. "Relational Thinking: A Critique of Co-Deterministic Theories of Structure and Agency." Sociological Theory 26 (1): 51-73.

Dezalay, Yves, and Bryant Garth. 2010. “Marketing and Selling Transnational 'Judges' and Global 'Experts': Building the Credibility of (Quasi)judicial Regulation.” Socio-Economic Review 8 (1): 113-30. doi:10.1093/ser/mwp022.

Dezalay, Yves, and Bryant G. Garth. 2016. “'Lords of the Dance’ as Double Agents: Elite Actors in and around the Legal Field." Journal of Professions and Organization 3 (2): 188-206. doi:10.1093/jpo/jow006.

Dezalay, Yves, and Michael Rask Madsen. 2017. “In the 'Field' of Transnational Professionals: A Post-Bourdieusian Approach to Transnational Legal Entrepreneurs." In Professional Networks in Transnational Governance, edited by Leonard Seabrooke and Lasse Folke Henriksen. Cambridge: Cambridge University Press.

Dezalay, Yves, and David Sugarman. 1995. Professional Competition and Professional Power: Lawyers, Accountants and the Social Construction of Markets. London; New York: Routledge. http://public.eblib.com/choice/publicfullrecord.aspx?p=242041.

Djelic, Marie-Laure, and Sigrid Quack. 2010. Transnational Communities: Shaping Global Economic Governance. Cambridge University Press.

Djelic, Marie-Laure, and Kerstin Sahlin-Andersson. 2006. Transnational Governance: Institutional Dynamics of Regulation. Cambridge University Press.

Durkheim, Emile. 1957. Professional Ethics and Civic Morals. London; New York: Routledge and Kegan Paul.

1997. The Division of Labor in Society. Translated by W. D. Halls. Simon and Schuster.

Ehrenreich, Barbara, and John Ehrenreich. 1979. "The Professional-Managerial Class.” In Between Capital and Labour, edited by Pat Walker, 55-75. Brighton: Harvester Press. 
Ellersgaard, Christoph Houman, Lasse Folke Henriksen, Peter Marcus Kristensen, and Anton Grau Larsen. 2017. "Social Spaces.” In Routledge Handbook of International Political Sociology, edited by Xavier Guillaume and Pinar Bilgin, 334-49. New York, NY: Routledge.

Ellersgaard, Christoph Houman, Anton Grau Larsen, Lasse Folke Henriksen, and Jacob Aagaard Lunding. 2016. "Pathways to the Power Elite: Career Trajectories in the Core of the Danish Networks of Power." Sequence Analysis and Related Methods (LaCOSA II), 847.

Emirbayer, Mustafa. 1997. "Manifesto for a Relational Sociology." American Journal of Sociology 103 (2): 281-317. doi:10.1086/231209.

Emirbayer, Mustafa, and Victoria Johnson. 2008. "Bourdieu and Organizational Analysis.” Theory and Society 37 (1): 1-44.

Eyal, Gil. 2013. "For a Sociology of Expertise: The Social Origins of the Autism Epidemic." American Journal of Sociology 118 (4): 863-907. doi:10.1086/668448.

Farrell, Henry, and John Quiggin. 2017. “Consensus, Dissensus and Economic Ideas: Economic Crisis and the Rise and Fall of Keynesianism." International Studies Quarterly.

Faulconbridge, James R, and Daniel Muzio. 2012. "Professions in a Globalizing World: Towards a Transnational Sociology of Professions.” International Sociology 27 (1).

Fourcade, Marion. 2006. "The Construction of a Global Profession: The Transnationalization of Economics.” American Journal of Sociology 112 (1): 145-94. doi:10.1086/502693.

Go, Julian, and Monika Krause. 2016a. "Fielding Transnationalism: An Introduction." The Sociological Review Monographs 64 (2): 6-30.

. 2016b. Fielding Transnationalism. 1 edition. Chichester, West Sussex, UK; Malden, MA: Wiley-Blackwell.

Gracia, Louise, and Lynne Oats. 2012. "Boundary Work and Tax Regulation: A Bourdieusian View." Accounting, Organizations and Society 37 (5): 304-21.

Haas, Peter M. 1992. "Introduction: Epistemic Communities and International Policy Coordination." International Organization 46 (1): 1-35.

Hall, Rodney Bruce, and Thomas J. Biersteker, eds. 2002. The Emergence of Private Authority in Global Governance. Cambridge Studies in International Relations 85. Cambridge: Cambridge University Press.

Hannerz, Ulf. 1996. Transnational Connections: Culture, People, Places. Psychology Press.

Harrington, Brooke. 2017. "Habitus and the Labor of Representation among Elite Professionals." Journal of Professions and Organization, February. doi:10.1093/jpo/jox002. 
Hasselbalch, Jacob. 2016. "Professional Disruption in Health Regulation: Electronic Cigarettes in the European Union." Journal of Professions and Organization 3 (1): 62-85. doi:10.1093/jpo/jov009.

Henriksen, Lasse Folke, and Leonard Seabrooke. 2016. "Transnational Organizing: Issue Professionals in Environmental Sustainability Networks.” Organization 23 (5): 722-741.

Hirschman, Daniel, and Elizabeth Popp Berman. 2014. "Do Economists Make Policies? On the Political Effects of Economics." Socio-Economic Review. http://ser.oxfordjournals.org/content/early/2014/04/15/ser.mwu017.short.

Kauppi, Niilo, ed. 2013. A Political Sociology of Transnational Europe. ECPR - Studies in European Political Science. Colchester, UK: ECPR Press.

Kauppi, Niilo, and Michael Rask Madsen. 2017. "Global Elites.” In Routledge Handbook of International Political Sociology, edited by Xavier Guillaume and Pinar Bilgin, 91-100. New York, NY: Routledge.

Kauppi, Niilo, and Mikael Madsen. 2013. Transnational Power Elites: The New Professionals of Governance, Law and Security. Routledge Studies in Liberty and Security. London; New York: Routledge.

Kauppi, Niilo, and Mikael R. Madsen. 2014. "Fields of Global Governance: How Transnational Power Elites Can Make Global Governance Intelligible.” International Political Sociology 8 (3): 324-30. doi:10.1111/ips.12060.

Keck, Margaret E., and Kathryn Sikkink. 1998. Activists beyond Borders: Advocacy Networks in International Politics. Ithaca, NY: Cornell University Press.

Leander, Anna. 2002. “Do We Really Need Reflexivity in IPE? Bourdieu's Two Reasons for Answering Affirmatively." Review of International Political Economy 9 (4): 601-9. doi:10.1080/0969229022000021817.

Lebaron, Frédéric. 2008. "Central Bankers in the Contemporary Global Field of Power: A 'social Space'approach.” The Sociological Review 56 (s1): 121-144.

Leicht, Kevin T., and Mary L. Fennell. 2008. "Institutionalism and the Professions." In The SAGE Handbook of Organizational Institutionalism, edited by Royston Greenwood, Christine Oliver, Roy Suddaby, and Kerstin Sahlin-Andersson, 431-48. Thousand Oaks, CA: Sage Publications.

Liu, Sida. 2015. "Boundary Work and Exchange: The Formation of a Professional Service Market: Boundary Work and Exchange.” Symbolic Interaction 38 (1): 1-21. doi:10.1002/symb.137. 
Liu, Sida, and Mustafa Emirbayer. 2016. "Field and Ecology." Sociological Theory 34 (1): 62-79.

Madsen, Mikael Rask. 2011. "Reflexivity and the Construction of the International Object: The Case of Human Rights1: Reflexivity and the International Object." International Political Sociology 5 (3): 259-75. doi:10.1111/j.1749-5687.2011.00133.x.

Martin, John Levi. 2003. “What Is Field Theory?” American Journal of Sociology 109 (1): 1-49.

Mattli, Walter, and Tim Büthe. 2003. "Setting International Standards: Technological Rationality or Primacy of Power?” World Politics 56 (01): 1-42.

Mennicken, Andrea. 2010. "From Inspection to Auditing: Audit and Markets as Linked Ecologies." Accounting, Organizations and Society 35 (3): 334-59. doi:10.1016/j.aos.2009.07.007.

Mudge, Stephanie L., and Antoine Vauchez. 2016. "Fielding Supranationalism: The European Central Bank as a Field Effect.” The Sociological Review Monographs 64 (2): 146-169.

Muzio, Daniel, David M. Brock, and Roy Suddaby. 2013. "Professions and Institutional Change: Towards an Institutionalist Sociology of the Professions: Professions and Institutional Change.” Journal of Management Studies 50 (5): 699-721. doi:10.1111/joms.12030.

Muzio, Daniel, James Faulconbridge, Claudia Gabbioneta, and Royston Greenwood. 2016. "Bad Apples, Bad Barrels and Bad Cellars: A 'Boundaries' Perspective on Professional Misconduct.” In Organizational Wrongdoing., edited by Palmer, D., Greenwood, R., and Smith-Crowe, K., 141-75. Cambridge, UK: Cambridge University Press.

Pattberg, Philipp. 2005. "The Institutionalization of Private Governance: How Business and Nonprofit Organizations Agree on Transnational Rules.” Governance: 18 (4): 589-610.

Powell, Walter W., Douglas R. White, Kenneth W. Koput, and Jason Owen-Smith. 2005. "Network Dynamics and Field Evolution: The Growth of Interorganizational Collaboration in the Life Sciences.” American Journal of Sociology 110 (4): 1132-1205. doi:10.1086/421508.

Quack, S. 2007. "Legal Professionals and Transnational Law-Making: A Case of Distributed Agency.” Organization 14 (5): 643-66. doi:10.1177/1350508407080313.

Saks, Mike. 2016. "A Review of Theories of Professions, Organizations and Society: The Case for Neo-Weberianism, Neo-Institutionalism and Eclecticism.” Journal of Professions and Organization 3 (2): 170-87. doi:10.1093/jpo/jow005.

Savage, Mike, and Karel Williams. 2008. "Elites: Remembered in Capitalism and Forgotten by Social Sciences." The Sociological Review 56 (s1): 1-24. 
Schinkel, Willem, and Mirko Noordegraaf. 2011. "Professionalism as Symbolic Capital: Materials for a Bourdieusian Theory of Professionalism." Comparative Sociology 10 (1): 67-96. doi:10.1163/156913310X514083.

Scott, W. R. 2008. "Lords of the Dance: Professionals as Institutional Agents.” Organization Studies 29 (2): 219-38. doi:10.1177/0170840607088151.

Seabrooke, Leonard. 2014. "Epistemic Arbitrage: Transnational Professional Knowledge in Action." Journal of Professions and Organization 1 (1): 49-64. doi:10.1093/jpo/jot005.

Seabrooke, Leonard, and Lasse Folke Henriksen, eds. 2017. Professional Networks in Transnational Governance. Cambridge: Cambridge University Press.

Seabrooke, Leonard, and Emelie Rebecca Nilsson. 2015. "Professional Skills in International Financial Surveillance: Assessing Change in IMF Policy Teams: Professional Skills in IMF Policy Teams." Governance 28 (2): 237-54. doi:10.1111/gove.12106.

Seabrooke, Leonard, and Eleni Tsingou. 2009a. "Power Elites and Everyday Politics in International Financial Reform.” International Political Sociology 3 (4): 457-461.

. 2009b. "Revolving Doors and Linked Ecologies in the World Economy: Policy Locations and the Practice of International Financial Reform." http://wrap.warwick.ac.uk/1849.

2015. "Professional Emergence on Transnational Issues: Linked Ecologies on Demographic

Change." Journal of Professions and Organization 2 (1): 1-18. doi:10.1093/jpo/jou006.

Stone, Diane. 2013. “'Shades of Grey”: The World Bank, Knowledge Networks and Linked Ecologies of Academic Engagement." Global Networks 13 (2): 241-260.

Suddaby, Roy, David J. Cooper, and Royston Greenwood. 2007. "Transnational Regulation of Professional Services: Governance Dynamics of Field Level Organizational Change.” Accounting, Organizations and Society 32 (4-5): 333-62. doi:10.1016/j.aos.2006.08.002.

Suddaby, Roy, and Daniel Muzio. 2015. "Theoretical Perspectives on the Professions." In The Oxford Handbook of Professional Service Firms, edited by Laura Empson, Daniel Muzio, Joseph Broschak, and Bob Hinings, 25-47.

Suddaby, Roy, and Thierry Viale. 2011. "Professionals and Field-Level Change: Institutional Work and the Professional Project." Current Sociology 59 (4): 423-42. doi:10.1177/0011392111402586.

Vauchez, Antoine. 2011. "Interstitial Power in Fields of Limited Statehood: Introducing a 'Weak Field' Approach to the Study of Transnational Settings.” International Political Sociology 5 (3): $340-345$. 


\section{DRAFT}

Weber, Max. 1968. Economy and Society: An Outline of Interpretive Sociology. New York: Bedminster Press. 